\title{
Fungi colonising leaves of evergreen rhododendron (Rhododendron L.) of the Botanic Garden of the Jagiellonian University in Kraków and the Arboretum of the Warsaw University of Life Sciences in Rogów
}

\author{
Grzyby zasiedlające liście różaneczników zimozielonych (Rhododendron L.) \\ w Ogrodzie Botanicznym Uniwersytetu Jagiellońskiego w Krakowie \\ i Arboretum Szkoły Głównej Gospodarstwa Wiejskiego w Rogowie
}

Joanna Kwiatkowska*

Summary

The aim of the study was to learn about the quantitative and species status of fungi living on rhododendrons (Rhododendron L.) of the Botanic Garden of the Jagiellonian University in Cracow and the Arboretum of the Warsaw University of Life in Rogów, which reduce the decorative value of leaves and contribute to the development of disease symptoms. Mycological analysis showed that on the leaves taken from $R$. dauricum, $R$. fortunei, $R$. catawbiense, $R$. brachycarpum and $R$. makinoi species of rhododendron there ware groups of pathogenic and saprotrophic fungi. Species of Pestalotiopsis sydowiana, Alternaria alternata, Penicillium expansum and Epicoccum nigrum dominated on the samples. Although the micromycetes communities differed in species composition and number of colonies, on both sites a comparable degree of plant colonisation by fungi was found.

Key words: micromycetes, fungi, Ericaceae, leaf spots, necrosis

\section{Streszczenie}

Celem badań było poznanie stanu ilościowego i gatunkowego grzybów bytujących na różanecznikach (Rhododendron L.) w Ogrodzie Botanicznym Uniwersytetu Jagiellońskiego w Krakowie i Arboretum Szkoły Głównej Gospodarstwa Wiejskiego w Rogowie, obniżających walory dekoracyjne liści oraz przyczyniających się do wywoływania objawów chorobowych. Na podstawie analizy mykologicznej wykazano, że na liściach pobranych z różanecznika dahurskiego ( $R$. dauricum), różanecznika Fortune’a $(R$. fortunei), różanecznika katawbijskiego (R. catawbiense), różanecznika krótkoowocowego ( $R$. brachycarpum) i różanecznika Makina (R. makinoi) bytował kompleks grzybów patogenicznych i saprotroficznych, wśród których dominowały: Pestalotiopsis sydowiana, Alternaria alternata, Penicillium expansum i Epicoccum nigrum. Na obydwu stanowiskach stwierdzono porównywalny ilościowy stopień zasiedlenia roślin przez grzyby, aczkolwiek zbiorowiska micromycetes różniły się między sobą składem gatunkowym.

Słowa kluczowe: micromycetes, grzyby, Ericaceae, plamistości liści, nekroza

Instytut Ogrodnictwa

Konstytucji 3 Maja 1/3, 96-100 Skierniewice

*corresponding author: joanna.kwiatkowska@inhort.pl

ORCID: 0000-0002-1844-9231 


\section{Wstęp / Introduction}

Różaneczniki (Rhododendron L.) charakteryzują się dekoracyjnym ulistnieniem, pokrojem, typem kwiatostanów, barwą i zapachem kwiatów oraz zimotrwałością. Grzyby znajdujące się w fyllosferze tych roślin mogą znacząco obniżać ich walory dekoracyjne, prowadzić do deformacji, zasychania i obumierania. Badania prowadzone na roślinach wrzosowatych, w tym na różanecznikach zimozielonych i na różanecznikach o opadających liściach (azaliach) Rhododendron sp., wykazały że grzyby oraz organizmy grzybopodobne są sprawcami wielu chorób, takich jak: antraknoza (Colletotrichum gloeosporioides), zgorzelowa plamistość różanecznika i zgorzel korzeni różanecznika - fytoftoroza (Phytophthora spp.), mączniak prawdziwy (Microsphaera penicillata, Erysiphe polyphaga), rak pędów (Phomopsis archeri, C. gloeosporioides), rizoktonioza (Rhizoctonia solani syn. Thanatephorus cucumeris), septorioza (Sphaerulina azaleae syn. Septoria azaleae), szara pleśń (Botrytis cinerea), zgorzele sadzonek (Pythium ultimum, Pythium splendens, R. solani, Fusarium spp., Cylindrocladium scoparium, Ilyonectria destructans syn. Cylindrocarpon destructans), rdza (Naohidemyces vaccinii syn. Pucciniastrum myrtilli, Puccinia rhododendri), gruboszowatość (Exobasidium vaccinii), srebrzysta plamistość liści różanecznika (Cercospora handelii), zgnilizna korzeni oraz plamistości liści i kwiatów (Calonectria morganii syn. Cylindrocladium scoparium, Phyllosticta cunninghamii, Ramularia angustara, S. azaleae, Sphaerulina solitaria), pierścieniowa plamistość liści (Myrothecium roridum), zamieranie pąków i pędów (Seifertia azaleae syn. Briosia azaleae), zgorzel kwiatów różanecznika (Ovulinia azaleae), brązowienie wierzchołków i brzegów liści (Pestalotia rhododendri, Truncatella truncatata syn. Pestalotiopsis trunca, Pestalotiopsis sydowiana syn. Pestalotia sydowiana) oraz opieńkowa zgnilizna korzeni i pędu - opieńka miodowa (Armillaria mellea) (Braun i Takamatsu 2000; Ing 2000; Inman i wsp. 2000; Łabanowski i wsp. 2001; Czekalski i Aniśko 2004; Shin i Mulenko 2004; Kowalik i wsp. 2006; Lebeda i wsp. 2007; Czekalski 2008; Orlikowski i wsp. 2010; Werner i Karolewski 2010; Kowalik i Bonio 2016).

Celem niniejszych badań była identyfikacja oraz przedstawienie stanu ilościowego i gatunkowego micromycetes bytujących na żywych i opadłych liściach różaneczników w Ogrodzie Botanicznym Uniwersytetu Jagiellońskiego w Krakowie i Arboretum Szkoły Głównej Gospodarstwa Wiejskiego w Rogowie.

\section{Materiały i metody / Materials and methods}

Badania nad zasiedlaniem liści różaneczników przez micromycetes przeprowadzono w latach 2012-2014 w Ogrodzie Botanicznym Uniwersytetu Jagiellońskiego w Krako- wie i Arboretum Szkoły Głównej Gospodarstwa Wiejskiego w Rogowie, w terminach: 25 maj, 25 lipiec i 25 wrzesień. W badaniach uwzględniono liście żywe i opadłe pobrane z różanecznika dahurskiego (Rhododendron dauricum), różanecznika Fortune'a ( $R$. fortunei), różanecznika katawbijskiego ( $R$. catawbiense), różanecznika krótkoowocowego ( $R$. brachycarpum) i różanecznika Makina ( $R$. makinoi). Do analiz mykologicznych, w każdym terminie, pobrano z krzewów po 10 liści żywych z objawami nekrozy i plamistości oraz po 10 liści opadłych. Prace laboratoryjne wykonano w Laboratorium Katedry Ochrony Roślin Wydziału Biotechnologii i Ogrodnictwa Uniwersytetu Rolniczego w Krakowie, w sterylnych warunkach, według standardowych metod stosowanych w mykologii. Z liści, z pogranicza tkanki żywej i z symptomami chorób, wycięto 5 fragmentów o powierzchni około $0,5 \mathrm{~cm}^{2}$. Porażone fragmenty liści poddano powierzchniowej dezynfekcji w 70\% alkoholu etylowym, ponownie trzykrotnie przepłukano w wodzie destylowanej, a następnie, w celu osuszenia, materiał roślinny umieszczono na bibule filtracyjnej, na szkiełkach okularowych. Osuszone fragmenty liści wyłożono na płytki Petriego, z zestaloną pożywką glukozowo-ziemniaczaną (PDA - Potato Dextrose Agar). Płytki zabezpieczono przed zewnętrznymi zanieczyszczeniami mikrobiologicznymi i pozostawiono w laboratorium w temperaturze pokojowej (ok. $20^{\circ} \mathrm{C}$ ) do wyrośnięcia kolonii grzybów. Po upływie 7 dni kolonie grzybów odszczepiono na skosy z zestaloną pożywką glukozowo-ziemniaczaną PDA. Grzyby oznaczono w oparciu o klucze mykologiczne: Guba (1961), Booth (1966, 1971), Rifai (1969), Ellis (1971), Domsch i wsp. (1980), Sutton (1980) oraz Ellis i Ellis (1987). W zestawieniach tabelarycznych uwzględniono ich aktualny status taksonomiczny według bazy Index Fungorum (listopad 2015 r.).

\section{Wyniki i dyskusja / Results and discussion}

O wywoływaniu przez micromycetes zmian chorobowych na roślinach wrzosowatych (Ericaceae) rosnących w Ogrodzie Botanicznym Uniwersytetu Jagiellońskiego w Krakowie i Arboretum Szkoły Głównej Gospodarstwa Wiejskiego w Rogowie, pisali: Bonio i Duda (2014), Duda i Bonio (2014), Kowalik i wsp. (2014a, b, 2015), Bonio i Drzewiecka (2016) oraz Kowalik i Bonio (2016). W niniejszych badaniach dokonano identyfikacji grzybów strzępkowych przyczyniających się do obniżania walorów dekoracyjnych liści różaneczników (Rhododendron L.). $\mathrm{Z}$ materiału roślinnego, pobranego $\mathrm{z}$ pięciu taksonów różanecznika o zimozielonych liściach, wyodrębniono 66 gatunków grzybów (tab. 1), co świadczy o dużej różnorodności gatunkowej grzybów zasiedlających liście różaneczników.

Z liści żywych z objawami nekrozy i plamistości wyizolowano 680 kolonii micromycetes, należących do 53 gatunków, natomiast z liści opadłych wyodrębniono 


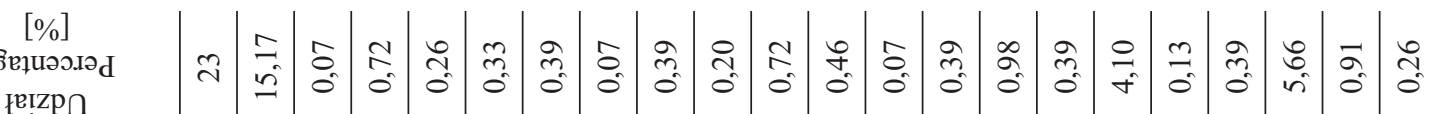

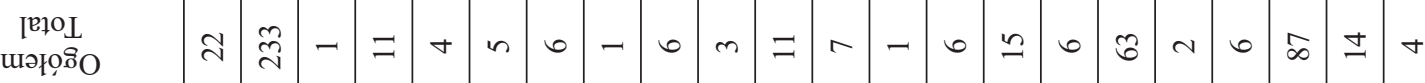

\begin{tabular}{|c|c|c|c|c|c|c|c|c|c|c|c|c|c|c|c|c|c|c|c|c|c|c|c|c|}
\hline \multirow{4}{*}{ 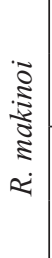 } & \multirow{2}{*}{ 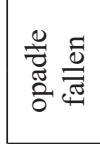 } & $\varangle$ & $\vec{\sim}$ & 9 & 1 & 1 & 1 & 1 & I & I & 1 & 1 & 1 & 1 & 1 & 1 & $\infty$ & 1 & $\infty$ & 1 & 0 & $\cong$ & 1 & $\mathrm{~N}$ \\
\hline & & $\stackrel{n}{0}$ & 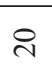 & $a$ & 1 & 1 & 1 & I & $m$ & 1 & 1 & - & 1 & 1 & 1 & 1 & 1 & 1 & $=$ & $\sim$ & I & 0 & in & 1 \\
\hline & \multirow{2}{*}{ 亨离 } & $\varangle$ & $\curvearrowright$ & $\infty$ & 1 & 1 & I & I & I & - & 0 & 1 & 1 & 1 & 1 & 1 & - & 1 & $\infty$ & 1 & 1 & - & 1 & 1 \\
\hline & & ڤै & $\stackrel{\infty}{-}$ & 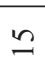 & 1 & 1 & $\sim$ & $n$ & I & 1 & 1 & 1 & $m$ & 1 & 1 & 1 & - & 1 & $r$ & 1 & I & $r$ & 1 & 1 \\
\hline
\end{tabular}

궁

党 设

焉

药

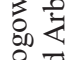

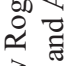

3

各

泣

言

(a)

흘 $\varangle=0$

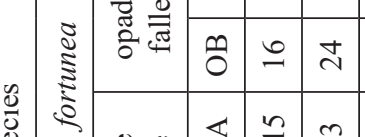

बं

蛋育

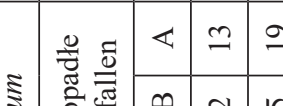

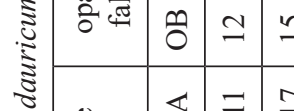

烄育

\%

离.

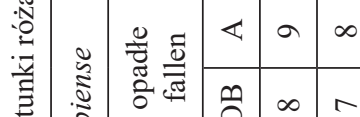

을

30

ह

तิ

苛

๑ึ.

需 吾

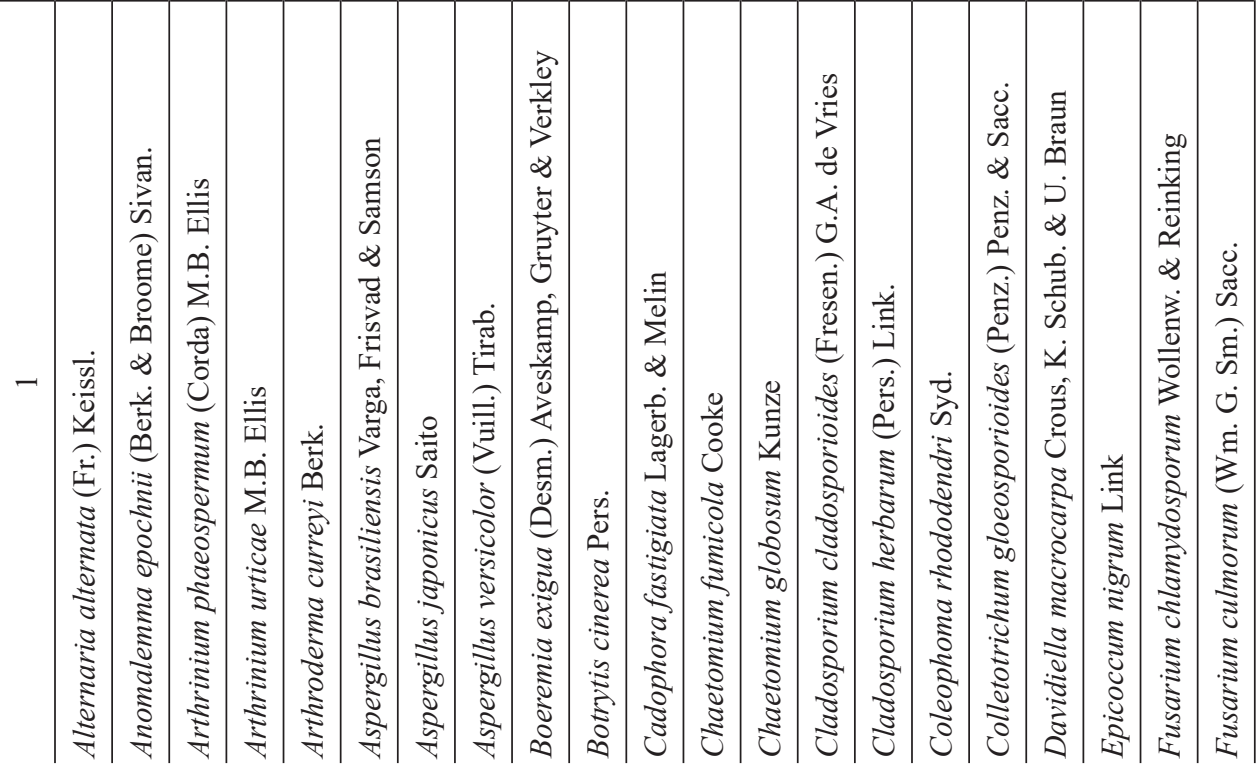




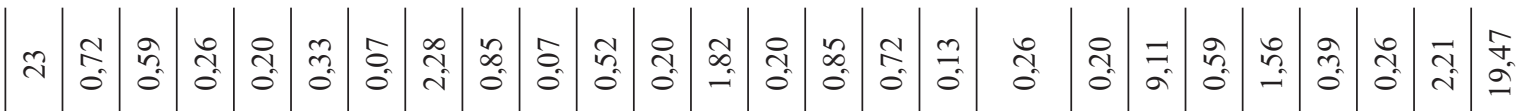

言

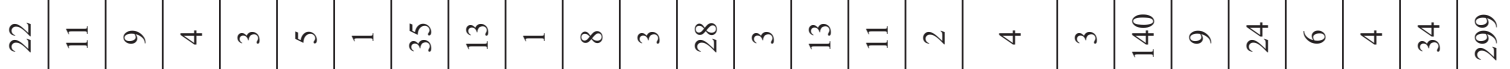
ㄱ

芩

굴

गुं $\cong$

ナ

ஸे ^ิ

율

윰

30

$\frac{1}{3}$

实

글

3

\begin{tabular}{ll|l|l|l|}
\hline & 1 & + & + &
\end{tabular}

\begin{tabular}{lllll|l|l|l|l|l|l|l|l|l|l|l|l|l|l|l}
1 & 1 & 1 & $m$ & 1 & 1 & 1 & 1 & - & 1 & 1 & 1 & - & - & + & 1 & 1 & + & $\hat{\imath}$ \\
\hline
\end{tabular}

.

总空 $=$

ㅇ

\begin{tabular}{|c|c|c|c|c|c|c|c|c|c|c|c|c|c|c|c|c|c|c|c|}
\hline 1 & 1 & 1 & $\infty$ & 1 & $\nabla$ & 1 & in & 1 & 1 & 1 & N & 1 & 1 & $m$ & - & $a$ & I & 1 & $\nabla$ \\
\hline
\end{tabular}

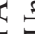

.$\frac{0}{3}$

章

$\frac{1}{3} \cdot \frac{0}{50}$

$5 \pm$

ह

ลี

亚

๑ొ

葡

कू⿱ 口)

$3 . \Xi$

3

获

氹

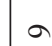

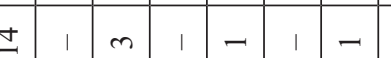

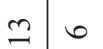

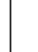

\begin{tabular}{l|l|l|l|l|}
1 & 1 & 1 & 1 & 1 \\
\hline
\end{tabular}

\begin{tabular}{l|l|l|l|l|l}
\hline & 1 & 1 & - & 1
\end{tabular}

।

\begin{tabular}{|l|l|l|l|l|l|l}
\hline & 1 & 1 & 1 & \\
\hline
\end{tabular}

.

$--$

\begin{tabular}{l|l|l|}
\hline & 1 \\
\hline & 1 & 1
\end{tabular}

\begin{tabular}{l|l}
1 \\
1
\end{tabular}

\begin{tabular}{|l|l|l|l}
\hline \\
\hline
\end{tabular}

\begin{tabular}{|c|c|c|}
\hline & 1 & \\
\hline 1 & $m$ & 0
\end{tabular}

尊

。

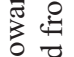

N $\frac{\pi}{0}$

कै

8

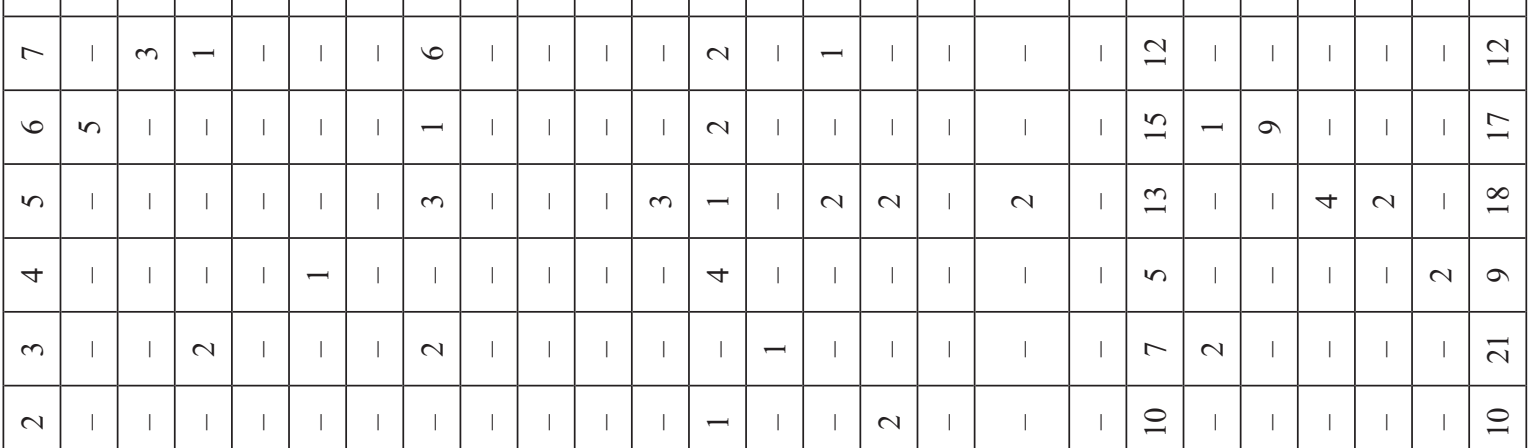

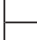

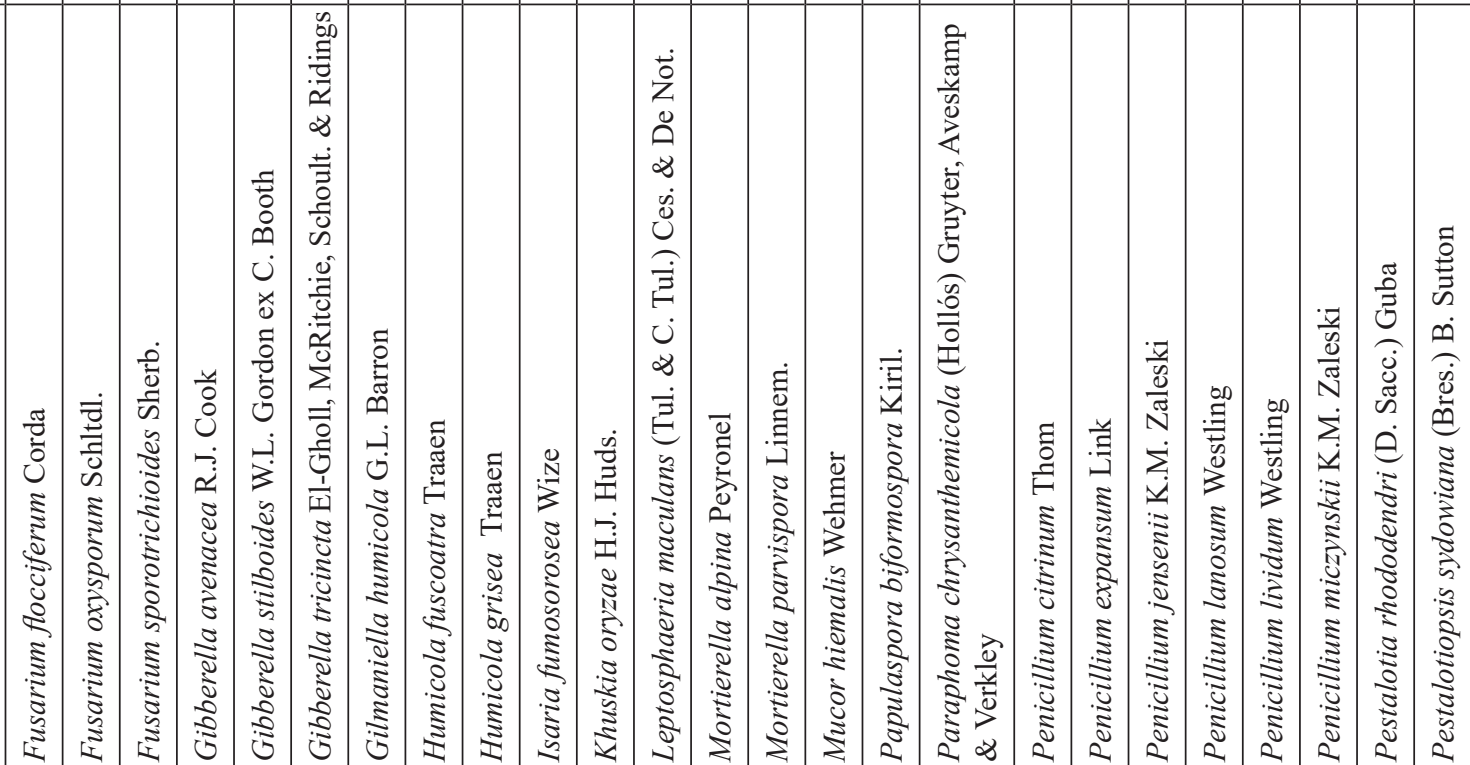

翌高 


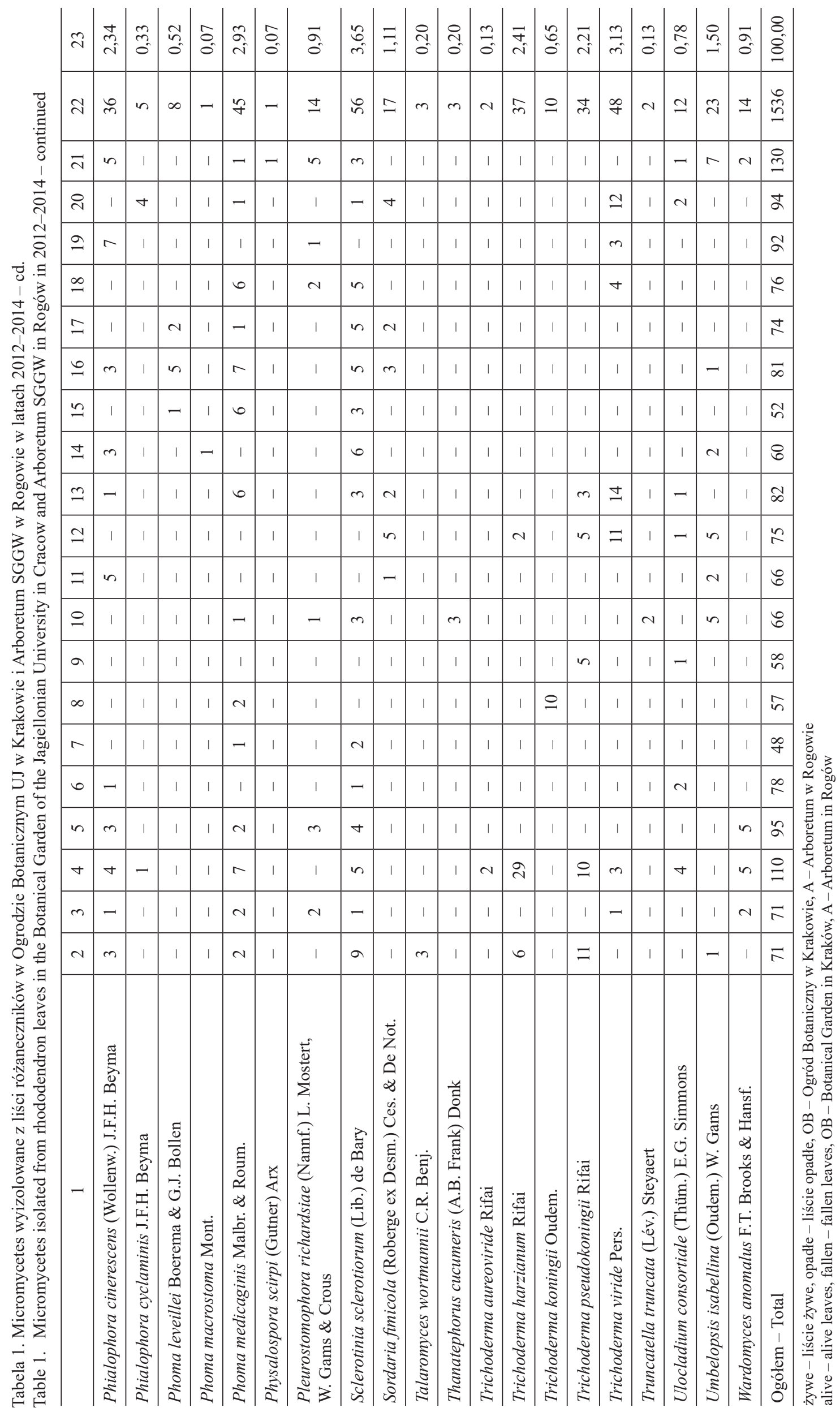


856 kolonii zaliczonych do 57 gatunków. Wyodrębnienie większej liczby gatunków grzybów z liści opadłych, dowodzi że są one wtórnie zasiedlane przez saprotrofy, które bytują, rozkładają i żywią się martwą materią organiczną. Czterdzieści cztery gatunki były wspólne, co może świadczyć o tym, iż grzyby te mogą bytować w fyllosferze różaneczników przez cały okres wegetacji. Wśród wyodrębnionych gatunków, z liści żywych i opadłych, najliczniej wystąpiły: Pestalotiopsis sydowiana, Alternaria alternata i Penicillium expansum. Znaczną liczebnością w całej populacji uzyskanych izolatów wyróżniły się grzyby rodzajów: Penicillium, Trichoderma, Epicoccum, Coleophoma, Sclerotinia i Phoma.

Z liści żywych, zielonych, ale z objawami nekrozy i plamistości, $\mathrm{z}$ pięciu taksonów różanecznika w największej częstotliwości izolowano: P. sydowiana (syn. Pestalotia sydowiana) i A. alternata, stanowiące ponad 36\% całości zbiorowiska. Częste występowanie $P$. sydowiana na roślinach wrzosowatych, we wcześniejszych badaniach opisali: Keith i wsp. (2006, 2010a, b, 2011a, b) oraz Żołna i wsp. (2013), przypisując mu rolę w powodowaniu licznych przebarwień i plamistości. Hopkins i McQuilken (2000) twierdzą, że P. sydowiana i gatunki rodzaju Pestalotia mogą powodować plamistości i nekrozy pędów różaneczników i innych roślin wrzosowatych, doprowadzając do ich zamierania, natomiast Łabanowski i wsp. (2001) grzybom tych rodzajów nie przypisują właściwości chorobotwórczych. W niniejszych badaniach wykazano, że poza $P$. sydowiana, na liściach różaneczników bytowały Pestalotia rhododendri i Pestalotia truncata (według Index Fungorum Truncatella truncata), które powinny być uznane za sprawców brązowienia brzegów i wierzchołków blaszek liściowych. Kowalik i wsp. (2010a) podają, że dominującą rolę w procesie wywoływania zmian chorobowych, w tym nekrotycznych plam, nasilonego zamierania i opadania liści, odgrywa toksynotwórczy grzyb A. alternata, który w bieżących badaniach należał do gatunków dominujących na żywych liściach różaneczników.

Ponadto z liści żywych wyodrębniono gatunki rodzaju Phoma, które jak podają wcześniejsze doniesienia (Kowalik i Muras 2007; Kowalik i wsp. 2011a, b), powodują objawy w postaci nekroz pędów oraz dużych, owalnych, nekrotycznych i ciemno obrzeżonych plam z widocznymi piknidiami na liściach oraz wywołują zgorzele pędów. W znacznej liczebności na liściach bytowały także rodzaje Fusarium i Gibberella, których gatunki, jak podaje Werner (1998), zakażają korzenie oraz szyjkę korzeniową ( $G$. avenacea) i niszczą wiązki przewodzące ( $F$. oxysporum), co prowadzi do stopniowego zamierania krzewów. Suchorzyńska i Misiewicz (2009), Żołna i wsp. (2013) oraz Kuzdraliński i wsp. (2014) donoszą, że skutkiem porażenia roślin mogą być nie w pełni rozwinięte kwiatostany, plamistości płatków kwiatowych oraz żółknięcie liści.

$\mathrm{Na}$ porażonych i znekrotyzowanych tkankach liści żywych, znaczący udział miał grzyb Coleophoma rhododendri, który w pracach Ellis i Ellis (1987) oraz Kowalik (2009) wymieniany jest jako patogen różaneczników i azalii. Z liści z objawami chorobowymi wyizolowano także $B$. cinerea, który jest sprawcą szarej pleśni, oraz jak podają Kowalik i wsp. (2006), powoduje brązowienie brzegów blaszek liściowych, rozległe nekrozy i gwałtowne zamieranie liści różaneczników. Kowalik i wsp. (2010a, b) podają, że w fyllosferze różanecznika zimozielonego licznie bytują gatunki rodzaju Trichoderma, co także potwierdzono w niniejszej pracy. Z liści z objawami nekrozy i plamistości wyodrębniono T. harzianum, T. pseudokoningii i T. viride, co świadczy o wtórnym zasiedleniu znekrotyzowanych tkanek przez saprotrofy. Ponadto wykazano, że gatunki: Cladosporium cladosporioides, Cladosporium herbarum, Epicoccum nigrum, Humicola fuscoatra, Mortierella alpina, Mortierella parvispora, Umbelopsis isabellina, Mucor hiemalis i Sordaria fimicola, jako saprotrofy potęgowały proces nekrotyzacji żywych liści różaneczników, czym obniżały walory dekoracyjne różaneczników, co znajduje potwierdzenie w literaturze (Łabanowski i wsp. 2001; Kita i Mazurek 2003; Kowalik 2008; Kowalik i wsp. 2010a, b). Dodatkowo na zielonych liściach różaneczników bytowały rodzaje: Arthrinium, Aspergillus, Chaetomium, Penicillium, Phialophora, Sclerotinia oraz Ulocladium, które we wcześniejszych pracach opisali: Kowalik i Muras (2007), Kowalik (2009) oraz Kowalik i wsp. (2007/2008).

$\mathrm{Z}$ liści opadłych zimozielonego różanecznika w największej liczebności izolowano P. sydowiana i A. alternata, a także grzyby rodzaju Penicillium oraz mniej liczne: Coleophoma, Epicoccum i Sclerotinia. Kowalik i Muras (2007) podają, że opadłe liście różaneczników najczęściej zasiedlają: A. alternata, P. sydowiana, P. hirsutum, M. alpina, Calonectria morganii, I. destructans, S. fimicola i $H$. fuscoatra oraz w mniejszej częstotliwości: E. nigrum, P. chrysanthemicola, $P$. richardsiae, Arthrobotrys arthrobotryoides i $B$. cinerea. Ponadto różaneczniki mogą ulec zakażeniu przez grzyby rodzajów: Cercospora, Colletotrichum, Cylindrocladium, Gleosporium, Macrophoma, Monochaetia i Septoria (Werner i Kwaśna 1998) oraz: Fusarium, Mucor, Phoma i Rhizoctonia (Kita i Mazurek 2003). W niniejszych badaniach potwierdzono zasiedlenie liści różaneczników przez gatunki z rodzajów: Alternaria, Botrytis, Coleophoma, Colletotrichum, Fusarium, Gibberella, Pestalotia i Pestalotiopsis oraz saprotrofy, potęgujące proces nekrotyzacji liści, należące do: Cladosporium, Davidiella, Epicoccum, Humicola, Mortieralla, Mucor, Penicillium, Phoma, Sordaria, Trichoderma i Umbelopsis. 


\section{Wnioski / Conclusions}

1. Z żywych i opadłych liści różaneczników, z objawami nekrozy i plamistości, wyodrębniono kompleks grzybów patogenicznych i saprotroficznych, wśród których dominowały: Pestalotiopsis sydowiana, Alternaria alternata, Penicillium expansum i Epicoccum nigrum.

2. Na liściach różaneczników w Ogrodzie Botanicznym Uniwersytetu Jagiellońskiego w Krakowie dominowały gatunki zaliczane do rodzajów Alternaria, Pestalotiopsis, Trichoderma i Penicillium, stanowiące 57\% wszystkich wyizolowanych grzybów.

3. Na liściach różaneczników w Arboretum Szkoły Głównej Gospodarstwa Wiejskiego w Rogowie, w największej liczebności bytowały gatunki grzybów zaliczane do rodzajów Pestalotiopsis, Alternaria i Penicillium, stanowiące $50 \%$ wszystkich wyodrębnionych kolonii.
4. Wyodrębnienie większej liczby gatunków grzybów z liści opadłych, świadczy o tym, że mogą być one wtórnie zasiedlane przez saprotrofy, które występując w górnej warstwie gleby, jako reducenci rozkładają martwą materię organiczną.

\section{Podziękowanie / Acknowledgements}

Wyniki przedstawione w pracy są częścią pracy doktorskiej wykonanej na Uniwersytecie Rolniczym w Krakowie. Składam serdeczne podziękowania i wyrazy uznania władzom Wydziału Biotechnologii i Ogrodnictwa oraz wszystkim pracownikom Zakładu Ochrony Roślin za nieocenioną pomoc i życzliwość.

\section{Literatura / References}

Bonio J., Drzewiecka L. 2016. Grzyby na liściach różanecznika Smirnowa Rhododendron smirnowii Grant. Materiały konferencyjne V Konferencji Naukowej „Nowe patogeny i choroby roślin”. Instytut Ogrodnictwa, Skierniewice, 6 kwietnia 2016, s. 11.

Bonio J., Duda K. 2014. Grzyby w fyllosferze bagna zwyczajnego Ledum palustre. Materiały konferencyjne IV Konferencji Naukowej „Nowe patogeny i choroby roślin”. Skierniewice, 8 kwietnia 2014, s. 11.

Booth C. 1966. The genus Cylindrocarpon. Mycological Papers 104, 56 ss.

Booth C. 1971. The Genus Fusarium. Commonwealth Mycological Institute, Kew, Surrey, England, 237 ss.

Braun U., Takamatsu S. 2000. Phylogeny of Erysiphe, Microphaera, Uncinula (Erysiphaceae) and Cystotheca, Podosphaera, Sphaerotheca (Cystotheceae) inferred from rDNA ITS sequences - some taxonomic sequences. Schlechtendalia 4: 1-33.

Czekalski M. 2008. Wrzosy, wrzośce i inne rośliny wrzosowate. Powszechne Wydawnictwo Rolnicze i Leśne, Warszawa, 236 ss. ISBN 978-83-09-01032-6.

Czekalski M., Aniśko T. 2004. Mączniak prawdziwy na różaneczniku żółtym - Rhododendron luteum Sweet. [Powdery mildew on Pontic azalea - Rhododendron luteum Sweet]. Erica Polonica. Rocznik Roślin Wrzosowatych 15: 39-42.

Domsch K.H., Gams W., Anderson T.H. 1980. Compendium of Soil Fungi. Academic Press, London, New York, Toronto, Sydney, San Francisco, 860 ss.

Duda K., Bonio J. 2014. Nekroza liści żurawiny wielkoowocowej Oxycoccus macrocarpus (Ait.) Pers. Materiały konferencyjne IV Konferencji Naukowej „Nowe patogeny i choroby roślin. Skierniewice, 8 kwietnia 2014, s. 15.

Ellis M.B. 1971. Dematiaceous Hyphomycetes. Commonwealth Mycological Institute, Kew, Surrey, England, 608 ss.

Ellis M.B., Ellis J.P. 1987. Microfungi on Land Plants. An Identification Handbook. Cromm Helm Ltd., London, Sydney, 818 ss.

Guba E.F. 1961. Monograph of Monochaetia and Pestalotia. Harvard University Press, Cambridge, 342 ss.

Hopkins K.E., McQuilken M.P. 2000. Characteristics of Pestalotiopsis associated with hardy ornamental plants in the UK. European Journal of Plant Pathology 106: 77-85. DOI: 10.1023/A:1008776611306

Ing B. 2000. Microsphaera azalea, the perfect stage of rhododendron mildew in England. Mycologist 14 (4): 165.

Inman A.J., Cook R.T.A., Beales P.A. 2000. A contribution on the identity of rhododendron powdery mildew in Europe. Journal of Phytopathology 148 (1): 17-27. DOI: 10.1046/j.1439-0434.2000.00456.x

Keith L.M., Velasquez M.E., Zee F.T. 2006. Identification and characterization of Pestalotiopsis spp. causing scab disease of guava, Psidium guajava, in Hawaii. Plant Disease 90 (1): 16-23. DOI: 10.1094/PD-90-0016

Kita W., Mazurek J. 2003. Skład gatunkowy fyllosfery różaneczników w Ogrodzie Botanicznym we Wrocławiu i w Arboretum w Wojsławicach. Erica Polonica 14: 25-36.

Kowalik M. 2008. Fungi and fungi-like Oomycetes isolated from affected leaves of rhododendron. [Grzyby i organizmy grzybopochodne Oomycetes wyizolowane z porażonych liści różanecznika]. Acta Mycologica 43 (1): 21-27.

Kowalik M. 2009. Bioróżnorodność grzybów występujących w fyllosferze różanecznika zimozielonego Rhododendron L. [Biodiversity of fungi occurring in phyllosphere of evergreen rhododendron (Rhododendron L.)]. Zeszyty Problemowe Postępów Nauk Rolniczych 539 (1): 341-348.

Kowalik M., Bonio J. 2016. Grzyby w fyllosferze delecji kantabryjskiej. Materiały konferencyjne V Konferencji Naukowej „Nowe patogeny i choroby roślin”. Instytut Ogrodnictwa, Skierniewice, 6 kwietnia 2016, s. 26.

Kowalik M., Bonio J., Duda K. 2014a. Micromycetes na liściach roślin wrzosowatych Ericaceae. W: Grzyby - organizmy kluczowe dla życia na Ziemi. [Fungi - key players in ecosystem functions]. Warsztaty Polskiego Towarzystwa Mykologicznego, Łódź-Spała. Polskie Towarzystwo Mykologiczne, Warszawa: 92-93. ISBN 978-83-940504-0-5. DOI: 10.13140/RG.2.1.1494.2241

Kowalik M., Bonio J., Duda-Franiak K. 2015. Micromycetes on ericaceous plant leaves. Acta Mycologica 50 (1): 1055. DOI: 10.5586/ am. 1055

Kowalik M., Duda K., Bonio J. 2014b. Zamieranie liści Chamaedaphne północna Chamaedaphne calyculata (L.) Moench. Materiały konferencyjne IV Konferencji Naukowej „Nowe patogeny i choroby roślin”. Skierniewice, 8 kwietnia 2014, s. 25. 
Kowalik M., Kierpiec B., Bonio J., Żołna M. 2011a. Plamistości i nekrozy na liściach azalii Rhododendron L. w Ogrodzie Botanicznym Uniwersytetu Jagiellońskiego. s. 278-281. W: Fitopatologia: zdrowe rośliny - zdrowi ludzie. [Phytopathology: healthy plants healthy people]. Bydgoszcz, 20-22 września 2011. Polskie Towarzystwo Fitopatologiczne, Uniwersytet Technologiczno-Przyrodniczy im. J. J. Śniadeckich w Bydgoszczy, 448 ss. ISBN 978-83-60775-31-8.

Kowalik M., Kierpiec B., Bonio J., Żołna M. 2011b. Fungi inhabiting spots and necroses on the leaves of azaleas (Rhododendron) in the Botanical Garden of the Jagiellonian University. [Grzyby zasiedlające plamistości i nekrozy na liściach azalii (Rhododendron) w Ogrodzie Botanicznym Uniwersytetu Jagiellońskiego]. Phytopathologia 62: 41-48.

Kowalik M., Muras P. 2007. Grzyby zasiedlające opadłe liście różanecznika. [Fungi occurring on the fallen leaves of rhododendron]. Roczniki Akademii Rolniczej w Poznaniu 333, Ogrodnictwo 41: 69-73.

Kowalik M., Muras P., Jurczyk A. 2007/2008. Grzyby obniżające walory dekoracyjne liści różanecznika. Erica Polonica 18: 7-12.

Kowalik M., Muras P., Kierpiec B., Żołna M. 2010a. Zdrowotność liści różaneczników zawsze zielonych Rhododendron L. [The leaf health of te leaves of the evergreen rhododendron Rhododendron L.]. Zeszyty Problemowe Postępów Nauk Rolniczych 551: 117-123.

Kowalik M., Muras P., Żołna M., Kierpiec B. 2010b. Grzyby wyosobnione z nekrotycznych plam na liściach różaneczników zawsze zielonych Rhododendron L. [Fungi isolated from necrotic spots on the leaves of evergreen rhododendrons Rhododendron L.]. Zeszyty Problemowe Postępów Nauk Rolniczych 554: 49-55.

Kowalik M., Oliwa A., Paliga A. 2006. Choroby różaneczników (Rhododendron L.) na terenach zieleni Krakowa. Erica Polonica 17: $33-41$.

Kuzdraliński A., Paterek A., Gierasimiuk N. 2014. Charakterystyka grzybów z rodzaju Fusarium oraz nowoczesne metody ich identyfikacji. Nauki Przyrodnicze 2 (4): 4-18.

Lebeda A., Sedlarova M., Jankovsky L., Shin H.D. 2007. First report of rhododendron powdery mildew on Rhododendron spp. in the Czech Republic. Plant Pathology 56 (2): 354. DOI: 10.1111/j.1365-3059.2007.01542.x

Łabanowski G., Orlikowski L., Soika G., Wojdyła A., Korbin M. 2001. Ochrona roślin wrzosowatych. Plantpress, Kraków, 77 ss.

Orlikowski L.B., Ptaszek M., Trzewik A., Orlikowska T., Wojtkowska M. 2010. Występowanie Phytophthora spp. w wodzie i chorobotwórczość wybranych izolatów P. citricola dla roślin. [Occurrence of Phytophthora spp. in water and pathogenicity of chosen isolates of Phytophthora citricola for plants]. Zeszyty Problemowe Postępów Nauk Rolniczych 554: 159-164.

Rifai M.A. 1969. A revision of the genus Trichoderma. Mycological Papers 116, 56 ss.

Shin H.D., Mulenko W. 2004. The record of Erysiphe azalea (Erysiphales) from Poland and its anamorph. Mycobiology 32 (3): $105-109$.

Suchorzyńska M., Misiewicz A. 2009. Mikotoksynotwórcze grzyby fitopatogeniczne z rodzaju Fusarium i ich wykrywanie technikami PCR. [Mycotoxigenic phythopathogenic fungi of Fusarium genus and their identification by PCR techniques]. Postępy Mikrobiologii 48 (3): 221-230.

Sutton B.C. 1980. The Coelomycetes. Fungi Imperfecti with Pycnidia Acervuli and Stromata. Commonwealth Mycological Institute, Kew, Surrey, England, 696 ss.

Werner M. 1998. Choroby odglebowe różanecznika. Ochrona Roślin 6: 12-13.

Werner M., Karolewski Z. 2010. The occurrence of powdery mildew on deciduous Rhododendron in Poland. [Występowanie mączniaka prawdziwego na rododendronach o liściach opadających w Polsce]. Phytopathologia 57: 31-38.

Werner M., Kwaśna H. 1998. Choroby pędów i liści różanecznika. Ochrona Roślin 8: 10-11.

Żołna M., Kierpiec-Baran B., Kowalik M. 2013. The diversity of fungi colonizing necrotic inflorescence buds of rhododendron (Rhododendron L.). [Różnorodność grzybów zasiedlających obumarłe pąki kwiatostanowe różanecznika zawsze zielonego (Rhododendron L.)]. Acta Agrobotanica 66 (2): 79-84. DOI: 10.5586/aa.2013.025 